\title{
Role performance of married working women as mother
}

\author{
RAJASHREE DUTTA BHARALI AND MINOTI PHUKAN
}

Received: 13.10.2015; Revised: 03.05.2016; Accepted: 14.05.2016

See end of the paper for authors' affiliations MINOTI PHUKAN

Department of Child Development and Family Relations, College of

Home Science, Assam Agricultural University, JORHAT (ASSAM) INDIA Email : phukan.minoti@ rediff.com
ABSTRACT : Working women are defined as the women who are engaged in gainful activities usually outside the home. The present study was undertaken to find out the role performance of working women as mother. A total of 120 married working women having children of class VI to $\mathrm{X}$ were selected purposively from four different wards of Jorhat, Assam. The findings of the study revealed that majority of working mothers always take care of their children in their overall development.

KEY WORDS: Working women

- HOW TO CITE THIS PAPER : Bharali, Rajashree Dutta and Phukan, Minoti (2016). Role performance of married working women as mother. Asian J. Home Sci., 11 (1) : 161-165, DOI: 10.15740/HAS/AJHS/ 11.1/161-165. 